\title{
Selectivity of pesticides used in rice crop on Telenomus podisi and Trichogramma pretiosum ${ }^{1}$
}

\author{
Juliano de Bastos Pazini², Anderson Dionei Grützmacher ${ }^{2}$, \\ José Francisco da Silva Martins ${ }^{3}$, Rafael Antônio Pasini², Matheus Rakes ${ }^{2}$
}

\section{ABSTRACT}

Telenomus and Trichogramma species stand out as agents for the biological control in rice crops, and the main strategy for preserving them is the use of selective pesticides. This study aimed at evaluating the toxicity of pesticides used in irrigated rice crop on Telenomus podisi Ashmead (Hymenoptera: Platygastridae) and Trichogramma pretiosum Riley (Hymenoptera: Trichogrammatidae). Adults of these parasitoids were exposed to dry residues of pesticides, in a completely randomized experiment, with 25 treatments $(24$ pesticides + control) and four replications. The insecticides clorantraniliprole, flubendiamide and diflubenzuron and the biological insecticides based on Beauveria bassiana and Metarhizium anisopliae were harmless to T. podisi and T. pretiosum. The harmless herbicides were: 2.4-D amine, profoxydim, quinclorac, ethoxysulfuron and saflufenacil. The fungicide epoxiconazole + kresoxim-methyl was also harmless to these two biological control agents. Therefore, these pesticides are indicated for the integrated pest management, in flooded rice areas.

KEY-WORDS: Oryza sativa; egg parasitoids; integrated pest management.

\section{INTRODUCTION}

Rice is one of the cereals with greatest economic and social importance worldwide, and Brazil is the largest producer outside the Asian continent (FAO 2015). Despite the high yield, in Brazil, rice crops are subject to the action of numerous pest organisms that cause economic losses. The predominant method for pest control consists of applying pesticides (Pazini et al. 2015), which can exert a negative influence on the population of natural enemies of insect pests (Lou et al. 2013).

\section{RESUMO}

Seletividade de pesticidas utilizados em arroz sobre Telenomus podisi e Trichogramma pretiosum

Espécies de Telenomus e Trichogramma destacam-se como agentes de controle biológico em áreas orizícolas, e a principal estratégia para sua preservação é a utilização de agrotóxicos seletivos. Objetivou-se avaliar a toxicidade de agrotóxicos utilizados em áreas de arroz irrigado sobre Telenomus podisi Ashmead (Hymenoptera: Platygastridae) e Trichogramma pretiosum Riley (Hymenoptera: Trichogrammatidae). Adultos desses parasitoides foram expostos a resíduos secos de agrotóxicos, em experimento inteiramente casualizado, com 25 tratamentos (24 agrotóxicos + testemunha) e quatro repetições. Os inseticidas clorantraniliprole, flubendiamida e diflubenzurom e os inseticidas biológicos à base de Beauveria bassiana e Metarhizium anisopliae foram inócuos para T. podisi e T. pretiosum. Os herbicidas inócuos foram: 2,4-D amina, profoxidim, quincloraque, etoxissulfurom e saflufenacil. O fungicida epoxiconazol + cresoximmetílico também foi inócuo para esses dois agentes de controle biológico. Portanto, esses agrotóxicos são indicados para o manejo integrado de pragas, em áreas de arroz irrigado.

PALAVRAS-CHAVE: Oryza sativa; parasitoide de ovos; manejo integrado de pragas.

The Telenomus and Trichogramma genera stand out as egg parasitoids of stinkbugs and lepidopterans that are being used for biological control in rice crops (Ko et al. 2014). Telenomus podisi Ashmead (Hymenoptera: Platygastridae) is a generalist species that parasitizes a wide range of hosts. T. podisi is among the most abundant species associated with oviposition of heteropterans in a number of crops (Pacheco \& Corrêa-Ferreira 2000, Maruyama et al. 2002, Godoy et al. 2005), such as in eggs of Tibraca limbativentris Stal (Hemiptera: Pentatomidae) (Riffel et al. 2010, Idalgo et al. 2013)

1. Manuscript received in Apr./2016 and accepted for publication in Sep./2016 (http://dx.doi.org/10.1590/1983-40632016v4640844). 2. Universidade Federal de Pelotas, Faculdade de Agronomia Eliseu Maciel, Departamento de Fitossanidade, Capão do Leão, RS, Brazil.E-mails: julianopazzini@hotmail.com, adgrutzm@ufpel.edu.br, rafa.pasini@yahoo.com.br, matheusrakes@hotmail.com. 3. Empresa Brasileira de Pesquisa Agropecuária (Embrapa Clima Temperado), Capão do Leão, RS, Brazil. 
and Glyphepomis adroguensis Berg (Hemiptera: Pentatomidae) (Farias et al. 2012) found in irrigated rice.

Egg parasitoids of the Trichogramma genus are reported as agents for the biological control of Lepidoptera pests in irrigated rice crops (Rani et al. 2007), in many countries. Some of the hosts are the eggs of the Asiatic rice borer Chilo suppressalis (Walker) (Lepidoptera: Crambidae) (Chen et al. 2010, Ko et al. 2014), the rice leafroller Cnaphalocrocis medinalis (Guenee) (Lepidoptera: Pyralidae) (Gurr et al. 2012) and the rice yellow stem borer Scirpophaga incertulas (Walker) (Lepidoptera: Crambidae) (Guo et al. 2002), among others. In Brazil, several species of Trichogramma have been described (Querino \& Zucchi 2003), and Trichogramma pretiosum Riley (Hymenoptera: Trichogrammatidae) is one of the most used for controlling Lepidoptera pests (Brugger et al. 2010, Stefanello Júnior et al. 2012).

The use of pesticides in rice crops is a reality, and integrated pest management is an alternative required (Sosbai 2014). Therefore, one strategy for the preservation of the parasitoids is to use selective insecticides, herbicides and fungicides, as well as other chemical and biological agents more harmless to natural enemies (Biondi et al. 2012). However, there is a lack of information on the adverse effects of the main insecticides, herbicides and fungicides on eggs parasitoids used for biological control in Brazil, in rice crops.

This study aimed at evaluating the selectivity of pesticides (insecticides, herbicides and fungicides) used in irrigated rice crop on adults of $T$. podisi and T. pretiosum egg parasitoids.

\section{MATERIAL AND METHODS}

The study was conducted at the Universidade Federal de Pelotas, in Capão do Leão, Rio Grande do Sul State, Brazil, between 2014 and 2015. The procedures followed standards adapted from the International Organisation for Biological and Integrated Control of Noxious Animals and Plants (IOBC) (Hassan et al. 2000, Carmo et al. 2010).

Eggs of alternate hosts Anagasta kuehniella (Zeller) (Lepidoptera: Pyralidae) (Parra 1997) and Euschistos heros (Fabricius) (Hemiptera: Pentatomidae) (Borges et al. 2006) and adults of T. pretiosum (Hassan et al. 2000) and T. podisi (Perez \& Corrêa-Ferreira 2004, Silva et al. 2008) were obtained from mass rearing in the laboratory (temperature: $25 \pm 1{ }^{\circ} \mathrm{C}$; relative humidity: $70 \pm 10 \%$; photophase: $14 \mathrm{~h}$ ).

A total of 24 pesticides that are commonly used in irrigated rice crop were evaluated on adults of T. podisi and T. pretiosum (Table 1). Selectivity bioassays were conducted with insecticides, herbicides and fungicides and a control treatment (distilled water). The doses used followed the registered maximum doses for rice and/or irrigated rice (Agrofit 2015) (Table 1), adjusted to a mix volume of $200 \mathrm{~L} \mathrm{ha}^{-1}$. The experimental design adopted was completely randomized, with 25 treatments (24 products + control) and four replications.

For the selectivity bioassays on adults of $T$. podisi, eggs of $E$. heros parasitized by $T$. podisi ( \pm 50 eggs) were deposited in emergence tubes (glass bottles of $12 \mathrm{~cm}$ long x $2 \mathrm{~cm}$ in diameter in one end and $0.7 \mathrm{~cm}$ in another) with a few drops of pure honey. The tubes were placed in an acclimatized room (temperature: $25 \pm 1{ }^{\circ} \mathrm{C}$; relative humidity: $70 \pm 10 \%$; photophase: $14 \mathrm{~h}$ ), until the parasitoids emergence. The pesticides were sprayed on glass plates $(13 \mathrm{~cm} \times 13 \mathrm{~cm})$, in a Potter tower, calibrated to deposit $1.75 \pm 0.25 \mathrm{mg}$ of mix per $\mathrm{cm}^{2}$. The edges of the plates were protected by a square plastic structure, so that only the central area measuring $10 \mathrm{~cm}$ x $10 \mathrm{~cm}$ was sprayed. After the drying period, the plates were fixed in contact cages, in a circulating air system (Hassan et al. 2000). The outer surfaces of the plates that were not treated were covered with black paper, with a square-shaped cut in the center $(7 \mathrm{~cm} \times 7 \mathrm{~cm})$, in order to concentrate the parasitoids in the treated area, attracted by the light. Emergence tubes with adult parasitoids ( $24 \mathrm{~h}$ of age) were attached to the cages, which were kept in an acclimatized room (temperature: $25 \pm 1{ }^{\circ} \mathrm{C}$; relative humidity: $70 \pm 10 \%$; photophase: $14 \mathrm{~h}$ ).

Twenty hours later, the emergence tubes were uncoupled. Eggs of E. heros (cards with \pm 100 eggs) were offered to the parasitoids in the cages, at $24 \mathrm{~h}, 48 \mathrm{~h}$ and $72 \mathrm{~h}$ after the pesticides spraying. The experiment was terminated after $96 \mathrm{~h}$ of parasitoids exposure to pesticide residues. After this period, the cards of eggs were removed from the cages and stored under the same test conditions to check for parasitism.

For the selectivity bioassays on adults of T. pretiosum, eggs of A. kuehniella parasitized by $T$. pretiosum $(250 \pm 50$ eggs $)$ were placed in emergence tubes containing a few drops of pure 
honey and stored (temperature: $25 \pm 1{ }^{\circ} \mathrm{C}$; relative humidity: $70 \pm 10 \%$, photophase: $14 \mathrm{~h}$ ) until the emergence of the parasitoids. The methods used for pesticide sprays, insertion of insects into the cages and coupling/decoupling of emergence tubes were the same previously described for the toxicity test with T. podisi.

Eggs of A. kuehniella on cards containing $450 \pm 50$ eggs each were offered to the parasitoids in cages at $24 \mathrm{~h}$ (three cards), $48 \mathrm{~h}$ (two cards) and $96 \mathrm{~h}$ (one card) after the pesticides spraying. The experiment was terminated after $168 \mathrm{~h}$ of parasitoids exposure to pesticide residues. After this period, the cards of eggs were removed from the cages and stored under the same test conditions to check for parasitism.

The mean number of parasitized eggs per female in each treatment was used to estimate parasitism. The parasitism reduction, compared to the control treatment, was calculated by the equation PR $(\%)=[(1-\mathrm{Vt} / \mathrm{Vc}) * 100]$, where $P R$ is the percentage of parasitism reduction, $V t$ the mean parasitism for the treatment and $V c$ the mean parasitism in the control treatment. Thereby, the pesticides were classified according to the IOBC standards: class 1: harmless (PR $<30 \%$ ); class 2 : slightly harmful $(30 \% \leq \mathrm{PR} \leq 79 \%)$; class 3 : moderately harmful $(80 \% \leq \mathrm{PR} \leq 99 \%)$; class 4 : harmful (PR > $99 \%)$.

The data on the mean number of eggs per female parasitized were subjected to the ShapiroWilk normality test and homogeneity of variances by the Bartlett test. If these assumptions were not met, the Kruskal-Wallis non-parametric analysis was carried out, and the average of the treatments were compared by the Dunn test, at $5 \%$. In case of normality and equality of variances, the means were compared by the Scott-Knott test, at $5 \%$. The R software 3.2.0 (R Development Core Team 2015) was used to carry out the tests.

Table 1. Pesticides used in irrigated rice crop on Telenomus podisi and Trichogramma pretiosum.

\begin{tabular}{|c|c|c|c|}
\hline Commercial product (c.p.) $^{\mathbb{B}}$ & Active ingredient & Formulation and concentration $^{\mathrm{I}}$ & Dose of c.p./ha ${ }^{\text {II }}$ \\
\hline \multicolumn{4}{|c|}{ Insecticide } \\
\hline Altacor & Chlorantraniliprole & WG 350 & 0.09 \\
\hline Belt* & Flubendiamide & SC 480 & 0.07 \\
\hline Boveril & Beauveria bassiana & WP - & 0.50 \\
\hline Engeo Pleno & Lambda-cyhalothrin + thiamethoxam & $\mathrm{SC} 106+141$ & 0.20 \\
\hline Incrível & Acetamiprid + alpha-cypermethrin & $\mathrm{SC} 100+200$ & 0.25 \\
\hline Karate Zeon 50 CS & Lambda-cyhalothrin & SC 50 & 0.15 \\
\hline Klap & Fipronil & SC 200 & 0.06 \\
\hline Metarril & Metarhizium anisopliae & WP - & 0.50 \\
\hline Micromite $240 \mathrm{SC}$ & Diflubenzuron & SC 240 & 0.10 \\
\hline Mustang $350 \mathrm{EC}$ & Zeta-cypermethrin & EC 350 & 0.04 \\
\hline Safety & Etofenprox & EC 300 & 0.30 \\
\hline \multicolumn{4}{|c|}{ Herbicide } \\
\hline Aminol 806 & 2.4-D amine & SL 806 & 1.50 \\
\hline Aura 200 & Profoxydim & DC 200 & 0.85 \\
\hline Facet & Quinclorac & WP 500 & 0.75 \\
\hline Gladium & Ethoxysulfuron & WG 600 & 0.13 \\
\hline Heat & Saflufenacil & WG 700 & 0.14 \\
\hline \multicolumn{4}{|c|}{ Fungicide } \\
\hline Aproach Prima & Picoxystrobin + cyproconazole & SC $200+80$ & 0.40 \\
\hline Brio & Epoxiconazole + kresoxim-methyl & $\mathrm{SC} 125+125$ & 1.00 \\
\hline Dithiobin $780 \mathrm{WP}$ & Thiophanate-methyl + mancozeb & WP $140+640$ & 2.50 \\
\hline Eminent $125 \mathrm{EW}$ & Tetraconazole & EW 125 & 0.50 \\
\hline Folicur $200 \mathrm{EC}$ & Tebuconazole & EC 200 & 0.75 \\
\hline Fox* & Trifloxystrobin + prothioconazole & $\mathrm{SC} 150+175$ & 0.40 \\
\hline Nativo $300 \mathrm{SC}$ & Trifloxystrobin + tebuconazole & $\mathrm{SC} 100+200$ & 0.75 \\
\hline Priori Xtra & Azoxystrobin + cyproconazole & $\mathrm{SC} 200+80$ & 0.30 \\
\hline
\end{tabular}

* Pesticides unregistered for rice and/or irrigated rice crop - registration dose in soybean crop (Agrofit 2015). ${ }^{\mathrm{I}}$ Formulation and concentration (mL $\left.\mathrm{L}^{-1} \mathrm{or}_{\mathrm{g}} \mathrm{kg}^{-1}\right)$ - EC: emulsifiable concentrate; EW: emulsion, oil in water; DC: dispersible concentrate; SC: suspension concentrate; SL: soluble concentrate; WG: water dispersible granule;

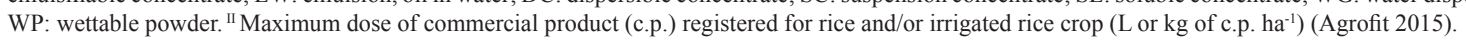




\section{RESULTS AND DISCUSSION}

Significant differences were observed in the parasitism reduction of $T$. podisi and $T$. pretiosum between the treatments with insecticides (Table 2). Chlorantraniliprole, flubendiamide, diflubenzuron and the biological insecticides based on Beauveria bassiana and Metarhizium anisopliae did not differ from the control, in terms of number of eggs parasitized, and were classified as harmless (class 1), with a parasitism reduction of no more than $10 \%$ for both parasitoids (Table 2).

The harmlessness of chlorantraniliprole was reported for $T$. pretiosum and other species of parasitoid eggs (Hymenoptera: Trichogrammatidae), such as Trichogramma dendrolimi Matsumura, Trichogramma chilonis Ishii and Trichogramma japonicum Ashmead (Preetha et al. 2009, Brugger et al. 2010, Uma et al. 2014). Similarly, flubendiamide is harmless to non-target organisms, such as predators and parasitoids (Sudhanan et al. 2014). Insecticides of the Diamides chemical group, such as chlorantraniliprole and flubendiamide, act on ryanodine receptors (Ebbinghaus-Kintscher et al. 2007), which cause insect death by preventing the normal muscle contractions of the insect. These compounds are very selective, since they act more specifically on phytophagous insects, primarily the Lepidoptera order (Stecca et al. 2014). In addition, they are considered harmless to natural enemies (Lahm et al. 2009), because they act by contact primarily through ingestion, as evidenced by our contact test with dry pesticide residues (Table 2).

Diflubenzuron was also selective to Telenomus remus Nixon (Hymenoptera: Platygastridae) (Carmo et al. 2010) and T. pretiosum (Carvalho et al. 1994). Insecticides like diflubenzuron, which is an insect growth regulator, have the ability to kill specifically the target insect and preserve the agents of biological control. Hormones that trigger the physiological molting process have different efficacy among the taxonomic orders of insects (Carmo et al. 2010). Pests and their natural enemies are generally from different orders. Moreover, insect growth regulators affect immature stages of insects during the whole molting process (Reynolds 1987), and, thus, adults of non-target species, such as parasitoids and predators, are rarely affected (Bastos et al. 2006). Lufenuron, triflumuron and novaluron, belonging to the Benzoylurea chemical group, as well as diflubenzuron, were also described as harmless to T. pretiosum (Carvalho et al. 2010) and may

Table 2. Effect of insecticides and biological insecticides used in irrigated rice crop on the mean number of parasitized eggs, parasitism reduction of Telenomus podisi and Trichogramma pretiosum and selectivity classification (temperature: $25 \pm 1{ }^{\circ} \mathrm{C}$; relative humidity: $70 \pm 10 \%$; photophase: $14 \mathrm{~h}$ ).

\begin{tabular}{|c|c|c|c|c|c|c|}
\hline \multirow[b]{2}{*}{ Active ingredient } & \multicolumn{3}{|c|}{ Telenomus podisi } & \multicolumn{3}{|c|}{ Trichogramma pretiosum } \\
\hline & $\begin{array}{l}\text { Eggs/female } \\
(\overline{\mathrm{x}} \pm \mathrm{EP})^{\mathrm{I}}\end{array}$ & $\begin{array}{l}\text { Parasitism } \\
\text { reduction }(\%)^{\mathrm{II}}\end{array}$ & Class $^{\mathrm{III}}$ & $\begin{array}{c}\text { Eggs/female } \\
(\bar{x} \pm \mathrm{EP})\end{array}$ & $\begin{array}{c}\text { Parasitism } \\
\text { reduction }(\%)\end{array}$ & Class \\
\hline \multicolumn{7}{|c|}{ Bioassay 1} \\
\hline Chlorantraniliprole & $5.7 \pm 0.6 \mathrm{a}^{\#}$ & 1.7 & 1 & $24.4 \pm 4.5 \mathrm{a}^{*}$ & 0.1 & 1 \\
\hline Lambda-cyhalothrin + Thiamethoxam & $0.0 \pm 0.0 \mathrm{c}$ & 100.0 & 4 & $0.0 \pm 0.0 \mathrm{~b}$ & 100.0 & 4 \\
\hline Lambda-cyhalothrin & $0.1 \pm 0.1 \mathrm{bc}$ & 97.9 & 3 & $0.0 \pm 0.0 \mathrm{~b}$ & 100.0 & 4 \\
\hline Fipronil & $0.0 \pm 0.0 \mathrm{c}$ & 100.0 & 4 & $0.0 \pm 0.0 \mathrm{~b}$ & 100.0 & 4 \\
\hline Etofenprox & $1.8 \pm 0.1 \mathrm{~b}$ & 68.8 & 2 & $0.0 \pm 0.0 \mathrm{~b}$ & 100.0 & 4 \\
\hline Control & $5.8 \pm 0.3 \mathrm{a}$ & - & - & $24.4 \pm 0.8 \mathrm{a}$ & - & - \\
\hline \multicolumn{7}{|c|}{ Bioassay 2} \\
\hline Flubendiamide & $5.4 \pm 0.6 \mathrm{a}^{\# \#}$ & 0.0 & 1 & $17.5 \pm 1.6 \mathrm{a}^{* *}$ & 9.7 & 1 \\
\hline Beauveria bassiana & $6.0 \pm 0.3 \mathrm{a}$ & 0.0 & 1 & $19.0 \pm 4.0 \mathrm{a}$ & 1.5 & 1 \\
\hline Acetamiprid + alpha-cypermethrin & $1.7 \pm 0.1 \mathrm{~b}$ & 65.0 & 2 & $0.7 \pm 0.3 \mathrm{~b}$ & 96.6 & 3 \\
\hline Metarhizium anisopliae & $4.3 \pm 0.3 \mathrm{a}$ & 9.0 & 1 & $23.0 \pm 5.2 \mathrm{a}$ & 0.0 & 1 \\
\hline Diflubenzuron & $4.7 \pm 0.9 \mathrm{a}$ & 1.6 & 1 & $17.5 \pm 1.5 \mathrm{a}$ & 9.3 & 1 \\
\hline Zeta-cypermethrin & $0.0 \pm 0.0 \mathrm{c}$ & 100.0 & 4 & $0.0 \pm 0.0 \mathrm{~b}$ & 100.0 & 4 \\
\hline Control & $4.8 \pm 0.7 \mathrm{a}$ & - & - & $19.3 \pm 2.0 \mathrm{a}$ & - & - \\
\hline
\end{tabular}

${ }^{\mathrm{I}}$ Mean + standard error (four replications) of parasitized eggs per female after $96 \mathrm{~h}$ (T. podisi) and $168 \mathrm{~h}$ (T. pretiosum) of parasitoids exposure to pesticide residues. ${ }^{\#}$ Results by Kruskal-Wallis $(\mathrm{H}=21.2010$; $\mathrm{p}$-value $=0.0007)$, followed by the Dunn test $(\mathrm{p}<0.05)$ * Results by Kruskal-Wallis $(\mathrm{H}=21.8216$; $\mathrm{p}$-value $=0.0006)$, followed by the Dunn test $(\mathrm{p}<0.05)$. Results by Anova $(\mathrm{F}=17.4249$; $\mathrm{p}$-value $=<0.0001)$, followed by the Scott-Knott test $(\mathrm{p}<0.05) . * *$ Results by Kruskal-Wallis $(\mathrm{H}=$ 17.5981; $\mathrm{p}$-value $=0.0073)$, followed by the Dunn test $(\mathrm{p}<0.05)$. ${ }^{\text {II }}$ Parasitism reduction in comparison to the control treatment. ${ }^{\mathrm{II}}$ IOBC classes: $1=$ harmless $(<30 \%)$; $2=$ slightly harmful $(30-79 \%) ; 3=$ moderately harmful $(80-99 \%) ; 4=$ harmful $(>99 \%)$. Means followed by the same letter, in the columns, do not differ significantly. 
be recommended for integrated pest management programs.

In line with the results obtained in this study, M. anisopliae was previously observed to be selective to adults of T. podisi, and did not affect their parasitism and viability, even when the parasitoids were exposed to direct contact with the fungus (Agüero \& Neves 2014). Amaro et al. (2015) assessed the toxicity of entomopathogens on adults of $T$. pretiosum and found that biological insecticides with the basis of $B$. bassiana and $M$. anisopliae do not reduce parasitism and are classified as harmless, meaning that they can be used safely in combination with the parasitoid. In addition, there was no reduction in the number of eggs parasitized by $T$. pretiosum, even in sprays of entomopathogens in pre and post-parasitism (Potrich et al. 2009).

Etofenprox and acetamiprid + alphacypermethrin, however, were classified as slightly harmful (class 2) to T. podisi, with number of eggs parasitized per female of 1.8 and 1.7 , representing a parasitism reduction, in relation to the control, of approximately $70 \%$ (Table 2 ). On the other hand, the remaining insecticides were more harmful to $T$. pretiosum. Acetamiprid + alphacypermethrin was classified as moderately harmful (class 3) and etofenprox as harmful (class 4), with high reductions in parasitism of up to $100 \%$ (Table 2). Lambda-cyhalothrin reduced parasitism of $T$. podisi and T. pretiosum by $97-100 \%$, while lambda-cyhalothrin + thiamethoxam, fipronil and zeta-cypermethrin reduced by $100 \%$, being classified as harmful (class 4) to both parasitoids (Table 2).
Neurotoxic insecticides, such as those belonging to the Pyrethroids and Neonicotinoids chemical groups, are generally classified as less-selective compounds to the egg parasitoids Telenomus spp. and Trichogramma spp. (Moura et al. 2006, Giolo et al. 2007, Stefanello Júnior et al. 2008a, Preetha et al. 2009, Carmo et al. 2010, Koppel et al. 2011, Goulart et al. 2012, Oliveira et al. 2013). As reported by Stefanello Júnior et al. (2008a), this toxicity originates from the similarity in the transmission mode of nerve impulses not only between the different orders of insects, but also between the various animal phyla.

There was no significant difference for the number of eggs parasitized by females of $T$. podisi and $T$. pretiosum between the herbicide treatments, therefore, all products were classified as harmless (class 1) (Table 3).

The results indicated that the herbicides had little effect on T. podisi and T. pretiosum populations. This is highly relevant, given that weeds are the main limiting factor for rice yield, and weed control is generally performed using herbicides (Sosbai 2014). Low toxicity to egg parasitoids in different developmental stages was also reported for herbicides registered for soybean (Carmo et al. 2009, Magano et al. 2013) and maize (Stefanello Júnior et al. 2008b and 2011).

Fungicides toxicity showed no significant difference for the average number of eggs parasitized by females of $T$. podisi and were classified as harmless to the parasitoid (Table 4). Fungicide sprays in rice fields predominate in the late booting stage of plants (Counce et al. 2000, Sosbai 2014), and the use

Table 3. Effect of herbicides used in irrigated rice crops on the mean number of parasitized eggs, parasitism reduction of Telenomus podisi and Trichogramma pretiosum and selectivity classification (temperature: $25 \pm 1{ }^{\circ} \mathrm{C}$; relative humidity: $70 \pm 10 \%$; photophase: $14 \mathrm{~h})$.

\begin{tabular}{|c|c|c|c|c|c|c|}
\hline \multirow[b]{2}{*}{ Active ingredient } & \multicolumn{3}{|c|}{ Telenomus podisi } & \multicolumn{3}{|c|}{ Trichogramma pretiosum } \\
\hline & $\begin{array}{c}\text { Eggs/female } \\
(\overline{\mathrm{x}} \pm \mathrm{EP})^{\mathrm{I}}\end{array}$ & $\begin{array}{c}\text { Parasitism } \\
\text { reduction }(\%)^{\mathrm{II}}\end{array}$ & Class $^{\mathrm{III}}$ & $\begin{array}{c}\text { Eggs/female } \\
(\bar{x} \pm \mathrm{EP})\end{array}$ & $\begin{array}{c}\text { Parasitism } \\
\text { reduction (\%) }\end{array}$ & Class \\
\hline 2.4-D amine & $5.1 \pm 0.4^{* \mathrm{~ns}}$ & 6.6 & 1 & $22.7 \pm 1.2 * * \mathrm{~ns}$ & 7.0 & 1 \\
\hline Profoxydim & $5.2 \pm 1.3$ & 5.2 & 1 & $19.6 \pm 3.6$ & 19.6 & 1 \\
\hline Quinclorac & $4.7 \pm 0.2$ & 14.1 & 1 & $22.4 \pm 2.6$ & 8.3 & 1 \\
\hline Ethoxyssulfuron & $4.3 \pm 0.4$ & 21.0 & 1 & $23.5 \pm 5.7$ & 3.6 & 1 \\
\hline Saflufenacil & $4.4 \pm 0.9$ & 19.9 & 1 & $19.0 \pm 2.8$ & 22.0 & 1 \\
\hline Control & $5.7 \pm 0.3$ & - & - & $24.4 \pm 0.92$ & - & - \\
\hline
\end{tabular}

${ }^{\mathrm{I}}$ Mean + standard error (four replications) of parasitized eggs per female after $96 \mathrm{~h}$ (T. podisi) and $168 \mathrm{~h}$ (T. pretiosum) of parasitoids exposure to pesticide residues. $*$ Results by Anova: $\mathrm{F}=0.3967 ; \mathrm{p}$-value $=0.8446 ;{ }^{\text {ns }}$ non-significant $(\mathrm{p}>0.05)$. * Results by Anova: $\mathrm{F}=0.4420 ; \mathrm{p}$-value $=0.8118 ;{ }^{\text {ns }}$ non-significant $(\mathrm{p}>0.05)$.

${ }^{\text {II }}$ Parasitism reduction in comparison to the control treatment. ${ }^{\mathrm{III}}$ IOBC classes: $1=$ harmless $(<30 \%) ; 2=$ slightly harmful $(30-79 \%) ; 3=$ moderately harmful $(80-99 \%)$; $4=$ harmful $(>99 \%)$. 
Table 4. Effect of fungicides used in irrigated rice crop on the mean number of parasitized eggs, parasitism reduction of Telenomus podisi and Trichogramma pretiosum and selectivity classification (temperature: $25 \pm 1{ }^{\circ} \mathrm{C}$; relative humidity: $70 \pm 10 \%$; photophase: $14 \mathrm{~h}$ ).

\begin{tabular}{|c|c|c|c|c|c|c|}
\hline \multirow[b]{2}{*}{ Active ingredient } & \multicolumn{3}{|c|}{ Telenomus podisi } & \multicolumn{3}{|c|}{ Trichogramma pretiosum } \\
\hline & $\begin{array}{c}\text { Eggs/female } \\
(\overline{\mathrm{x}} \pm \mathrm{EP})^{\mathrm{I}}\end{array}$ & $\begin{array}{c}\text { Parasitism } \\
\text { reduction }(\%)^{\mathrm{II}}\end{array}$ & Class ${ }^{\mathrm{III}}$ & $\begin{array}{c}\text { Eggs/female } \\
(\overline{\mathrm{x}} \pm \mathrm{EP})^{\mathrm{I}}\end{array}$ & $\begin{array}{c}\text { Parasitism } \\
\text { reduction }(\%)\end{array}$ & Class \\
\hline \multicolumn{7}{|c|}{ Bioassay 1} \\
\hline Epoxiconazole + kresoxim-methyl & $4.0 \pm 0.4^{\mathrm{ns \#}}$ & 9.4 & 1 & $20.0 \pm 2.1 b^{*}$ & 24.6 & 1 \\
\hline Thiophanate-methyl + mancozeb & $3.7 \pm 0.2$ & 15.3 & 1 & $7.4 \pm 0.9 \mathrm{~d}$ & 72.3 & 2 \\
\hline Tetraconazole & $5.1 \pm 0.7$ & 0.0 & 1 & $5.4 \pm 0.9 \mathrm{~d}$ & 79.7 & 2 \\
\hline Trifloxystrobin + tebuconazole & $4.9 \pm 0.3$ & 0.0 & 1 & $14.1 \pm 1.8 \mathrm{c}$ & 47.0 & 2 \\
\hline Control & $4.4 \pm 0.3$ & - & - & $26.6 \pm 2.0 \mathrm{a}$ & - & - \\
\hline \multicolumn{7}{|c|}{ Bioassay 2} \\
\hline Picoxystrobin + cyproconazole & $4.7 \pm 0.5^{\text {ns\# }}$ & 13.4 & 1 & $0.5 \pm 0.3 \mathrm{~d}^{* *}$ & 98.2 & 3 \\
\hline Tebuconazole & $4.5 \pm 0.7$ & 18.0 & 1 & $5.4 \pm 0.7 \mathrm{bc}$ & 77.7 & 2 \\
\hline Trifloxystrobin + prothioconazole & $4.5 \pm 0.3$ & 17.0 & 1 & $1.0 \pm 0.3 \mathrm{~cd}$ & 96.0 & 3 \\
\hline Azoxistrobina + ciproconazol & $4.7 \pm 0.8$ & 15.0 & 1 & $17.0 \pm 2.8 \mathrm{ab}$ & 30.0 & 2 \\
\hline Control & $5.47 \pm 0.39$ & - & - & $24.3 \pm 1.1 \mathrm{a}$ & - & - \\
\hline
\end{tabular}

${ }^{\mathrm{I}}$ Mean + standard error (four replications) of parasitized eggs per female after $96 \mathrm{~h}$ (T. podisi) and $168 \mathrm{~h}$ (T. pretiosum) of parasitoids exposure to pesticide residues. ${ }^{\#}$ Results by Anova: $\mathrm{F}=2.1349 ; \mathrm{p}$-value $=0.1267 ;{ }^{\mathrm{ns}}$ non-significant $(\mathrm{p}>0.05) .{ }^{*}$ Results by Anova $(\mathrm{F}=29.5532 ; \mathrm{p}$-value $=<0.0001)$, followed by the Scott-Knott test $(\mathrm{p}<0.05) .{ }^{\#}$ Results by Anova: $\mathrm{F}=0.4993 ; \mathrm{p}$-value $=0.7367 ;{ }^{\text {ns }}$ non-significant $(\mathrm{p}>0.05) . * *$ Results by Kruskal-Wallis $(\mathrm{H}=17.2000 ; \mathrm{p}-\mathrm{value}=0.0018)$, followed

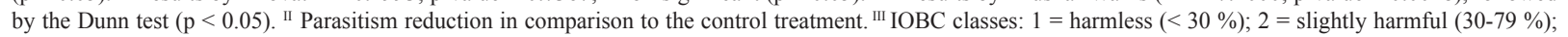
$3=$ moderately harmful ( $80-99 \%) ; 4=$ harmful (>99\%). Means followed by the same letter, in the columns, do not differ significantly.

of selective compounds does not affect the potential for natural parasitism of stinkbug eggs occurring after this period in the crop (Riffel et al. 2010, Idalgo et al. 2013). Other studies also describe the reduced effect of the fungicides Triazole and Strobilurins on adults, larvae and pupae of T. remus, in soybean crops (Carmo et al. 2009 and 2010).

Fungicides were more harmful to T. pretiosum, if compared to T. podisi. Thiophanate-methyl + mancozeb, tetraconazole, trifloxystrobin + tebuconazole, tebuconazole and azoxystrobin + cyproconazole were classified as slightly harmful (class 2) (Table 4). Picoxystrobin + cyproconazole and trifloxystrobin + prothioconazole, however, were classified as moderately harmful (class 3 ). Only epoxiconazole + kresoxim-methyl was harmless (class 1) for both parasitoids. Magano et al. (2015) obtained similar results with these compounds in a study on the side effects of fungicides registered for disease control on adults of T. pretiosum, in soybean.

In general, adults of $T$. podisi seem to be more tolerant than adults of T. pretiosum to the toxic effects of insecticides, herbicides and fungicides (Tables 2, 3 and 4). Carmo et al. (2009) also observed this difference, with T. remus being more tolerant than T. pretiosum, both in the egg and pupa phases.

It is important to consider that, based on the methodology used in this study, the adults from the egg parasitoids were subjected to the maximum contact with pesticides, under laboratory conditions and no-choice tests. Under field conditions, pesticide effects may be minimized by their own degradation, or even because parasitoids may escape to untreated areas. Thus, additional tests under semi-field and/ or field conditions, with the pesticides classified as moderately harmful (class 3) and harmful (class 4), recommended by the IOBC (Hassan et al. 2000), should be carried out for the completion of the side effects classification.

Information obtained in this study constitutes a pioneering and important step to choose pesticides selective to egg parasitoids used for the integrated pest management of lowland rice crops. In addition, this information may be useful to integrate management practices for the preservation of these natural enemies in other crops also conducted in this agro-ecosystem, such as soybean and maize.

\section{CONCLUSIONS}

1. The chemical insecticides chlorantraniliprole, flubendiamide, diflubenzuron; biological insecticides based on Beauveria bassiana and Metarhizium anisopliae; herbicides 2.4-D amine, profoxydim, quinclorac, ethoxysulfuron and saflufenacil; and fungicide epoxiconazole + 
kresoxim-methyl are harmless to Telenomus podisi and Trichogramma pretiosum, and are therefore the most suitable for the integrated pest management in flooded rice areas;

2. The insecticides lambda-cyhalothrin + thiamethoxam, lambda-cyhalothrin, fipronil, etofenprox, acetamiprid + alpha-cypermethrin and zeta-cypermethrin, as well as the fungicides picoxystrobin + cyproconazole and trifloxystrobin + prothioconazole, are harmful to at least one of the agents for biological control and are, therefore, not recommended for the integrated pest management in flooded rice areas;

3. T. podisi has higher tolerance than T. pretiosum to pesticides used in flooded rice areas.

\section{ACKNOWLEDGMENTS}

The authors thank Mariane D'avila Rosenthal (Universidade Federal de Pelotas), for full assistance in mass rearing of insects in laboratory; Coordenação de Aperfeiçoamento de Pessoal de Nível Superior (Capes), for providing a Master's scholarship; and Conselho Nacional de Desenvolvimento Científico e Tecnológico (CNPq), for the financial support (Grant number 308769/2013-9).

\section{REFERENCES}

AGROFIT: sistema de agrotóxicos fitossanitários. 2015. Available at: $<$ http://agrofit.agricultura.gov.br/agrofit cons/principal_agrofit_cons $>$. Access on: Dec. 14, 2015.

AGÜERO, M. A. F.; NEVES, P. M. O. J. Seletividade de Metarhizium anisopliae a Telenomus podisi (Hymenoptera: Platygastridae). Investigación Agraria, v. 16, n. 1, p. 2128, 2014.

AMARO, J. T. et al. Selectivity of organic products to Trichogramma pretiosum Riley (Hymenoptera: Trichogrammatidae). Neotropical Entomology, v. 44, n. 5 , p. 489-497, 2015.

BASTOS, C. S.; ALMEIDA, R. P. de; SUINAGA, F. A. Selectivity of pesticides used on cotton (Gossypium hirsutum) to Trichogramma pretiosum reared on two laboratory-reared hosts. Pest Management Science, v. 62, n. 1, p. 91-98, 2006.

BIONDI, A. et al. Using organic-certified rather than synthetic pesticides may not be safer for biological control agents: selectivity and side effects of 14 pesticides on the predator Orius laevigatus. Chemosphere, v. 87, n. 7, p. 803-812, 2012.
BORGES, M. et al. Metodologias de criação e manejo de colônias de percevejos da soja (Hemiptera - Pentatomidae) para estudos de comportamento e ecologia química. Brasília, DF: Embrapa Recursos Genéticos e Biotecnologia, 2006.

BRUGGER, K. E. et al. Selectivity of chlorantraniliprole to parasitoid wasps. Pest Management Science, v. 66, n. 10, p. 1075-1081, 2010.

CARMO, E. L. do et al. Pesticide selectivity for the insect egg parasitoid Telenomus remus. BioControl, v. 55, n. 4, p. 455-464, 2010.

CARMO, E. L. do et al. Seletividade de diferentes agrotóxicos usados na cultura da soja ao parasitoide de ovos Telenomus remus. Ciência Rural, v. 39, n. 8, p. 22932300, 2009.

CARVALHO, G. A. et al. Selectivity of growth regulators and neonicotinoids for adults of Trichogramma pretiosum (Hymenoptera: Trichogrammatidae). Revista Colombiana de Entomologia, v. 36, n. 2, p. 195-201, 2010.

CARVALHO, G. A. et al. Seletividade de inseticidas reguladores de crescimento de insetos a Trichogramma pretiosum Riley (Hymenoptera: Trichogrammatidae). Anais da Sociedade Entomológica do Brasil, v. 23, n. 3, p. 431-434, 1994.

CHEN, H. F. et al. Control efficacy of Trichogramma japonicum against Chilo suppressalis and Chilaraea auricilia. Chinese Journal of Applied Ecology, v. 21, n. 3, p. 743-748, 2010.

COUNCE, P. A. et al. A uniform, objective, and adaptative system for expressing rice development. Crop Science, v. 40, n. 2 , p. $436-443,2000$.

EBBINGHAUS-KINTSCHER, U. et al. Flubendiamide, the first insecticide with a novel mode of action on insect ryanodine receptors. Pflanzenschutz-Nachr Bayer, v. 60, n. 2, p. 117-140, 2007.

FARIAS, P. M. de et al. First records of Glyphepomis adroguensis (Hemiptera, Pentatomidae) and its parasitoid, Telenomus podisi (Hymenoptera, Platygastridae), on irrigated rice fields in Rio Grande do Sul, Brazil. Revista Brasileira de Entomologia, v. 56, n. 3, p. 383-384, 2012.

FOOD AND AGRICULTURE ORGANIZATION OF THE UNITED NATIONS (FAO). Faostat. 2015. Available at: $<$ http://faostat3.fao.org/browse/rankings/countries_by_ commodity/E > . Access on: Jan. 07, 2016.

GIOLO, F. P. et al. Seletividade de produtos fitossanitários utilizados na cultura do pessegueiro a Trichogramma pretiosum Riley, 1879 (Hymenoptera: Trichogrammatidae). Ciência e Agrotecnologia, v. 31, n. 5, p. 1396-1401, 2007.

GODOY, K. B. et al. Parasitismo em ovos de percevejos da soja Euschistus heros (Fabricius) e Piezodorus guildinii 
(Westwood) (Hemiptera: Pentatomidae) em São Gabriel do Oeste, MS. Ciência Rural, v. 35, n. 2, p. 455-458, 2005.

GOULART, R. M. et al. Insecticide selectivity to two species of Trichogramma in three different hosts, as determined by IOBC/WPRS methodology. Pest Management Science, v. 68, n. 2, p. 240-244, 2012.

GUO, H. F. et al. Egg parasitism of rice stem borers in regions with different rice stem borer occurring patterns. Chinese Journal of Biological Control, v. 18, n. 1, p. 1316, 2002.

GURR, G. M. et al. Parasitoids of the rice leaffolder Cnaphalocrocis medinalis and prospects for enhancing biological control with nectar plants. Agricultural and Forest Entomology, v. 14, n. 1, p. 1-12, 2012.

HASSAN, S. A. et al. A laboratory method to evaluate the side effects of plant protection products on Trichogramma cacoeciae Marchal (Hym., Trichogrammatidae). In: CANDOLFI, M. P. et al. (Eds.). Guidelines to evaluate side-effects of plant protection products to non-target arthropods. Gent: IOBC/WPRS, 2000. p. 107-119.

IDALGO, T. D. N. et al. Parasitismo de ovos de Tibraca limbativentris Stål (Hemiptera: Pentatomidae) em lavoura de arroz irrigado, Eldorado do Sul, RS. Arquivos do Instituto Biológico, v. 80, n. 4, p. 453-456, 2013.

KO, K. et al. Evaluation for potential Trichogramma (Hymenoptera: Trichogrammatidae) strains for control of the striped stem borer (Lepidoptera: Crambidae) in the Greater Mekong Subregion. Journal of Economic Entomology, v. 107, n. 3, p. 955-963, 2014.

KOPPEL, A. L. et al. Efficacy of selected insecticides against eggs of Euschistus servus and Acrosternum hilare (Hemiptera: Pentatomidae) and the egg parasitoid Telenomus podisi (Hymenoptera: Platygastridae). Journal of Economic Entomology, v. 104, n. 1, p. $137-$ 142, 2011.

LAHM, G. P. et al. New and selective ryanodine receptor activators for insect control. Bioorganic \& Medicinal Chemistry, v. 17, n. 12, p. 4127-4133, 2009.

LOU, Y. G. et al. Biological control of rice insect pests in China. Biological Control, v. 6, n. 1, p. 8-20, 2013.

MAGANO, D. A. et al. Efeitos secundários de herbicidas aplicados em soja sobre Trichogramma pretiosum. Pesquisa Agropecuária Gaúcha, v. 19, n. 1/2, p. 49-56, 2013.

MAGANO, D. A. et al. Evaluating the selectivity of registered fungicides for soybean against Trichogramma pretiosum Riley, 1879 (Hymenoptera: Trichogrammatidae). African Journal of Agricultural Research, v. 10, n. 40, p. 3825-3831, 2015.
MARUYAMA, W. I. et al. Parasitoides de ovos de percevejos (Hemiptera: Heteroptera) em plantas daninhas. Revista Ceres, v. 49, n. 284, p. 453-459, 2002.

MOURA, A. P. et al. Selectivity evaluation of insecticides used to control tomato pests to Trichogramma pretiosum. BioControl, v. 51, n. 6, p. 769778, 2006.

OLIVEIRA, H. N. de et al. Seletividade de inseticidas utilizados na cana-de-açúcar a adultos de Trichogramma galloi Zucchi (Hymenoptera: Trichogrammatidae). Bioscience Journal, v. 29, n. 5, p. 1267-1274, 2013.

PACHECO, D. J. P.; CORRÊA-FERREIRA, B. S. Parasitismo de Telenomus podisi Ashmead (Hymenoptera: Platygastridae) em populações de percevejos pragas da soja. Anais da Sociedade Entomológica do Brasil, v. 29, n. 2, p. 295-302, 2000.

PARRA, J. R. P. Técnicas de criação de Anagasta kuehniella, hospedeiro alternativo para produção de Trichogramma. In: PARRA, J. R. P.; ZUCCHI, R. A. (Eds.). Trichogramma e o controle biológico aplicado. Piracicaba: Fealq, 1997. p. 121-150.

PAZINI, J. de B. et al. Geoestatística aplicada ao estudo da distribuição espacial de Tibraca limbativentris em arrozal irrigado por inundação. Ciência Rural, v. 45, n. 6, p. 1006-1012, 2015.

PERES, W. A. A.; CORRÊA-FERREIRA, B. S. Methodology of mass multiplication of Telenomus podisi Ash. and Trissolcus basalis (Woll.) (Hymenoptera: Platygastridae) on eggs of Euschistus heros (Fab.) (Hemiptera: Pentatomidae). Neotropical Entomology, v. 33, n. 4, p. 457-462, 2004.

POTRICH, M. et al. Seletividade de Beauveria bassiana e Metarhizium anisopliae a Trichogramma pretiosum Riley (Hymenoptera: Trichogrammatidae). Neotropical Entomology, v. 38, n. 6, p. 822-826, 2009.

PREETHA, G. et al. Toxicity of selected insecticides to Trichogramma chilonis: assessing their safety in the rice ecosystem. Phytoparasitica, v. 37, n. 3, p. 209-215, 2009.

QUERINO, R. B.; ZUCCHI, R. A. Caracterização morfológica de dez espécies de Trichogramma (Hymenoptera: Trichogrammatidae) registradas na América do Sul. Neotropical Entomology, v. 32, n. 4, p. 597-613, 2003.

R DEVELOPMENT CORE TEAM. $R$ : a language and environment for statistical computing. rev. 3.2.0. Vienna: R Foundation for Statistical Computing, 2015.

RANI, P. U. et al. Kairomones extracted from rice yellow stem borer and their influence on egg parasitization by Trichogramma japonicum Ashmead. Journal of Chemical Ecology, v. 33, n. 1, p. 59-73, 2007. 
REYNOLDS, S. E. The cuticule, growth regulators and moulting in insects: the essential background to the action of acylurea insecticides. Pesticide Science, v. 20, n. 2, p. 131-146, 1987.

RIFFEL, C. T. et al. Primeiro relato de ocorrência de Telenomus podisi (Ashmead) e Trissolcus urichi (Crawford) (Hymenoptera : Platygastridae) como parasitoides de ovos do percevejo-do-colmo-do-arroz, Tibraca limbativentris (Stål) (Hemiptera: Pentatomidae), em Santa Catarina. Neotropical Entomology, v. 39, n. 3, p. 447-448, 2010.

SILVA, C. C. et al. Euschistus heros mass rearing technique for the multiplication of Telenomus podisi. Pesquisa Agropecuária Brasileira, v. 43, n. 5, p. 575-580, 2008.

SOCIEDADE SUL-BRASILEIRADEARROZIRRIGADO (Sosbai). Arroz irrigado: recomendações técnicas da pesquisa para o Sul do Brasil. Santa Maria: Sosbai, 2014.

STECCA, C. dos S. et al. Insecticide selectivity for Doru lineare (Dermaptera: Forficulidae). Revista Brasileira de Milho e Sorgo, v. 13, n. 1, p. 107-115, 2014.

STEFANELLO JÚNIOR, G. J. et al. Efeito de inseticidas usados na cultura do milho sobre a capacidade de parasitismo de Trichogramma pretiosum Riley, 1879 (Hymenoptera: Trichogrammatidae). Arquivos do Instituto Biológico, v. 75, n. 2, p. 187-194, 2008a.
STEFANELLO JÚNIOR, G. J. et al. Seletividade de herbicidas registrados para a cultura do milho a adultos de Trichogramma pretiosum (Hymenoptera: Trichogrammatidae). Planta Daninha, v. 26, n. 2, p. 343351, 2008b.

STEFANELlo JÚNiOR, G. J. et al. Persistência de agrotóxicos utilizados na cultura do milho ao parasitoide Trichogramma pretiosum Riley, 1879 (Hymenoptera: Trichogrammatidae). Ciência Rural, v. 42, n. 1, p. 17-23, 2012.

STEFANELLO JÚNIOR, G. J. et al. Seletividade de herbicidas registrados para a cultura do milho aos estádios imaturos de Trichogramma pretiosum (Hymenoptera: Trichogrammatidae). Planta Daninha, v. 29, special n., p. 1069-1077, 2011.

SUDHANAN, M. E. et al. Toxicity of flubendiamide 20 WG against egg parasitoid, Trichogramma chilonis (Ishii) (Hymenoptera: Trichogrammatidae) under laboratory conditions. Journal of Biological Control, v. 28, n. 3, p. 147-150, 2014.

UMA, S. et al. Acute contact toxicity of selected conventional and novel insecticides to Trichogramma japonicum Ashmead (Hymenoptera: Trichogrammatidae). Journal of Biopesticides, v. 7, n. 1, p. 133-136, 2014. 